\title{
Writing Brochure as Apart of Learning Material Development in Writing for Media Subject
}

\author{
Sumira $^{1}$, Desi Yulastri ${ }^{2}$, Muthia Damaiyanti ${ }^{3}$, Ofra Regina $^{4}$ \\ \{1 ${ }^{1}$ sumiradoano@gmail.com\} \\ 1,2,3,4 English Department, Politeknik Negeri Padang, Kampus Limau Manis, Padang, Indonesia
}

\begin{abstract}
Writing brochure is one of the material given to the English department students of Politeknik Negeri Padang (PNP) in Writing for Media subject. Realizing that writing brochure is different from academic writing, it is a need to formulate a model of writing a brochure as a part of learning material development in Writing for Media subject. This Research and Development used ADDIE Model (2015)and implements only 2 phases, analyzing and designing phase. In Analyzing phase, Curriculum analysis and Need Analysis were done. For curriculum analysis, observation and interview were conducted to determine the basic competence that need to be reached by the student and its appropriateness with the available learning material. Then, need analysis was done in order to find out the components that need to be written down in the brochure so that the field observation and interview were conducted. The result of this research is a model of printed travel package brochure written in English that consist of 686 words.
\end{abstract}

Keywords: Brochure; Writing for Media, Learning Material Development

\section{Introduction}

Entering 4.0 industry, most all of company compete to encourage their existence in all aspects: human resources, products, facilities and others. All of the efforts could not be mean without good promotion. Promotion is an effort to introduce the goods, things, services to the customer. There are many ways that can be used as a media for promotion. One of them is through brochure. Hsieh and O'Leary in Uysal define Brochure is promotional documents, primarily used to introduce a company, organization, products or services and inform prospective customers or members of the public of the benefits [1]. It is a paper document that can be folded into a template, pamphlet or leaflet; distributed in many different ways: as newspaper inserts, handed out personally, by mail or placed in brochure racks in high traffic locations especially in tourist precincts.

Writing brochure is one of the material given to the English department students of Politeknik Negeri Padang (PNP) in Writing for Media subject after they passed several writing subjects: Writing I, which focused on constructing sentences, and paragraphs; Writing II, which focused on writing essays; and Technical Writing, which focused on writing letters. While in Writing for Media Communication subject, the students are introduced with some type of writing that will be published in many kind of media; printed, electronic and online.

Writing brochure is different from writing academic English, as , Hartsook in Yulianti states that the things that must be considered in writing a brochure [2] as follows: do not use more than nine or ten lines of type per paragraph, do not average more than two or three sentences per paragraph, do not indent paragraphs that have a space between them, do not start sentences with numbers, do not put two spaces after periods if using a computer, do not use 
underline or all capitals as a way to stress a point. Use bold or italics instead, use italic and all capitals sparingly as they are hard for people to read. In addition there are two contents of strategy in designing a brochure. They are visual strategic as verbal (headlines, body copy, slogans, and closing words) and non-verbal visual strategic as (format of design, illustration, layout, logo, typography, color). Thus there are some steps which have to be follow in order to produce a qualified brochure. Lengkey at all, described six steps in creating brochure [3] as follows.

Concepting. This is the first step in writing a brochure which starting from identifying the type of brochure and target reader, determining the concept content, and specifying the purpose contained. Designing. There are two kind of design needed for creating a brochure; form of text and images. Material Collecting. The materials needed include photos and video, as well as supplementary data as an additional data.

Assembly. This is the steps where all of the data collected have to arrange in a good format by using application such as Adobe Photoshop CS6, Fotor, Adobe Premiere Pro CS6, iMovie, as well as Screen Creator. The next steps is Testing. Trials and testing process are carried out after completion of making design with showing the application/program or the result of the brochure and see if there are errors/shortcomings or not. Finally Distribution is output of all the process above.

Realizing that writing brochure is different from writing academic English, it is a need to formulate a model of writing a brochure as a part of learning material development in Writing for Media subject since the English department students of PNP have to produce it in English. Hence this research will discuss about the "Writing Brochure as a Part of Learning Material Development in Writing for Media Subject"

\section{Method}

This Research and Development used ADDIE Model [4]. ADDIE model consists of 5 Phase, analyzing, designing, development, implementation and evaluation. Since this research is a part of Developing Learning material for Writing for Media Subject In English Department, Politeknik Negeri Padang, so this research is conducted only in 2 phases, analyzing and designing phase.

First, In Analyzing Phase, the significance of writing brochure in developing Writing for Media Subject Learning material is described. Then, The learning purposes, and learning material is designed in Designing Phase. In Analyzing phase, Curriculum analysis and Need Analysis were done. For curriculum analysis, observation and interview were conducted to determine the basic competence that need to be reached by the student and its appropriateness with the available learning material. Then, need analysis was done in order to find out the components that need to be written down in the brochure so that the field observation and interview were done.

Second, In designing phase there are three steps applied, concepting, material colllecting and designing.

Concepting the brochure is starting from identifying the type of brochure, determining the content concept, specifying the purpose contained in this brochure and additional component that should be included in this brochure. Because this brochure is a service product brochure about " 4 Days 3 Nights Explore Wonderful Minangkabau", so detail information about those service products, in form of a tour package is provided. 
Material collecting as the second step of designing this brochure is done by collecting some materials and data needed in the brochure such as: image data of tourist attractions, hotels, some information about foods and tourist activities. These data were collected as a complement and become the main focus to make the brochure looks attractive. In this stage, the real data about hotel prices and the price list of Minangkabau tour packages filled in this brochure. Then, image data about tourism objects and traditional Minangkabau uniqueness such as: special food, cultural and natural tourist attractions. The pictures about traditional food and several cultural and natural attraction such as: Pagaruyuang palace, Pandai Sikek village, and Arau Villey on the Google were taken. While some pictures of the other natural and cultural attractions, are gotten from several photographer such as: Bukittinggi, Padang old city, Tarusan and Kiniko Home Industry. The pictures were : Jam Gadang, the historical building in Padang old city, Teluk Mandeh and the activities view of Kiniko Home Indutri.

Besides collecting image data about touris attractions, several pictures of star hotel rates 2,3 and 4 were also included in the brochure. After collecting data of tourist attraction and hotels the material needed next was the data of tour package based on the price of the hotel rates and tourist attractions that had been determined. In collecting this data, price calculations for individual and groups tour packages from several travel agent sources are gotten from Travel Agent and the website. So, the price listed in the brochure is accurate and in accordance with the facilities obtained.

In Designing stage were divided into content design and brochure layout design. On the design of the written content, making an outline, determining the language and writing procedure that fits in this brochure, created draft content before and after revision, and determine the final draft.

For the first draft, there were four paragraphs which have different explanations about itenerary tour in each paragraph. From Day 1 until Day 4 in the first draft contained all of the information needed on the brochure before correction done into the final draft. Next was cheking the first draft to the proofreader, to check whether the content has a good diction and grammar

The Second draft is the draft after corection from proofreader. There were some grammar errors and less punctuation. Proofreader edited as well as he did to correct the wrong content. Then, the final draft was made as the final version.

For the brochure layout design, photoshop application was used. Design the shape of the potrait and divide it into two parts, namely the front as a cover and the back as an explanation of the contents of the brochure. In the cover, a combined image of tourist objects in the tour package was made. There was also information about tourism attractions list that will be visited by tourist. The pictures are the main elements to show the tour package products offered in the brochure. Several pictures of tourist attractions highlighting as the main focus for the front look of brochure and Jam Gadang picture as the iconic picture.Meanwhile, for the design on the back of the brochure, a list of package prices, facilities included in this tour packageand also some pictures of attractions and hotel facilities offered.

\section{Result and Discussion}

A travel package brochure obtained from this research is the result from consecutive procedure of planning, material collecting, designing and assembling. There are 686 words in this brochure and it is written in English version only. Related to the learning material of Writing for Media subject, writing brochure is conducted as part of writing advertisement unit 
of learning based on the syllabus of Writing for Media subject. In this learning process, the students need to have the skill and knowledge in writing the brochure. Writing structured information, selecting the informative words and sentences, and formatting the lay out of the brochure are the skills the students acquire in finishing the brochure. All the skills acquired here are written in the syllabus of the subject.

Furthermore, the brochure content is collected based on the observation and interview gathered in the field. The interview was taken from several travel agents in West Sumatera including the travel agent of UPW (tourism travel business) of PNP. The interview conducted to gain information on the tour package for several tours that would be included in the brochure. In addition, the pictures that would be inserted in the brochure were taken from the internet and also the hotel websites.

In writing the brochure, there are several issues that need to be conveyed as part of learning material. First is the language use. The intonation and the sound of the sentences used in the brochure need to be clear and brief. The communicative approach is applied in constructing the sentences in the brochure. The sentences construction need to be written in correct grammar. The procedure of writing process need to be applied: planning, drafting, editing, and final draft. The students have to experience all of these procedures. Before the process finished, the proofreaders need to be involved in order to make the writing script obtained the best result. All of these components should be the standard for the students in finishing writing brochure.

The second issue is the content of the brochure. The students need to determine the type of the brochure that they want to write. Having the tour package brochure as the subject in this research means that the students need to think critically before starting to write down the content of the brochure. The Concepting procedure should be applied and experienced in the process of writing brochure.

The third issue is the design of the brochure. In this stage, the students need to have their own creativity in order to create the brochure as interesting as possible. The students may choose carefully the pictures inserted in the brochure as well as the colors used in the brochure. In addition, the students need to create the brochure cover and select the best pictures and words to be inserted in the cover. Here, the skill in using photoshop or either coreldraw application is needed.

Furthermore, the lay out or the format of the brochure should be thought carefully. Here, the students need to search other same brochures whether from the internet or from other sources in order to learn about the lay out or the format of the brochure. From the above explanation it can be said that the process in writing the brochure is quite different from writing other academic writing. The students should be aware of this and may increase the their skill in writing the brochure.

\section{Conclusion}

Brochure is significant to be put in learning material because it is one of promotion media. The characteristics and the components are different from academic writing so that the specific details and content need to be explored. For making this brochure, writing and grammar used need to be considered. The content in the brochure must be communicative and easy to understand, so that messages and information can be conveyed well to the target reader. The writing in the brochure also uses simple sentences, to explain the cultural terms in the brochure. 


\section{Acknowledgment}

We would like to thank P3M PNP which have facilitated financially the researchers in conducting this project. Thanks also goes to Head of English Department Ms. Martini who always support her staff. Thanks to all the media company as the informants for this research

\section{References}

[1] M. Uysal and D. R. Fesenmaier, Communication and Channel Systems in Tourism Marketing, vol. 2, no. 2-3. Psychology Press, 1993.

[2] Y. K.R., "Literature Review," in Literature Review of Brochure, Palembang: Politeknik Sriwijaya, 2014.

[3] D. M. Lengkey, Y. D. Y. Rindengan, and V. Tulenan, "Brosur Fakultas Teknik Universitas Sam Ratulangi Manado dengan Teknologi Markerless Augmented Reality," E-Journal Tek. Elektro Dan Komput., vol. 3, no. 4, pp. 1-10, 2014.

[4] Rosita, "Penerapan Model Pembelajaran ADDIE untuk Meningkatkan Hasil Belajar Akuntansi Siswa pada SMK PABA BINJAI," Liabilities J. Pendidik. Akunt., vol. 2, no. 1 , pp. $68-87,2019$. 